\title{
Predictive Power of Humor Types in Explaining Leadership Styles in Different Organizations
}

\author{
Muammer ERGÜN (iD) a Mustafa Öztürk AKCAOĞLU (iD b \\ a Kastamonu University, Department of Educational Sciences, Faculty of Education, Kastamonu, Turkey. mergun@kastamonu.edu.tr \\ b Kastamonu University, Department of Educational Sciences, Faculty of Education, Kastamonu, Turkey. ozturk@kastamonu.edu.tr
}

\begin{tabular}{|c|c|}
\hline ARTICLE INFO & ABSTRACT \\
\hline $\begin{array}{l}\text { Keywords: } \\
\text { Humor types } \\
\text { Leadership styles } \\
\text { Organizational behavior } \\
\text { Subordinates }\end{array}$ & $\begin{array}{l}\text { Purpose - Humor could act as a therapeutic agent for the employees by creating an entertaining } \\
\text { environment. It is also considered as a valuable administrative tool to increase production and } \\
\text { workers' productivity. Leadership, on the other hand, is an important component of all kinds of } \\
\text { organizations. Humor and leadership have been studied extensively in a variety of contexts. } \\
\text { Although the relationship between humor types and leadership styles has become a topic of interest } \\
\text { for the researchers, the predictive power of humor types in explaining leadership styles has not been } \\
\text { studied. The aim of this study is to find out whether the subordinates' views regarding the type of } \\
\text { their leaders differ and the type of humor predict leadership style of the managers. }\end{array}$ \\
\hline $\begin{array}{l}\text { Received } 9 \text { January } 2020 \\
\text { Revised } 15 \text { March } 2020 \\
\text { Accepted } 20 \text { March } 2020\end{array}$ & $\begin{array}{l}\text { Design/methodology/approach - The study employed survey research design. To this end, } 225 \\
\text { subordinates working at different organizations in a city located in Black Sea Region, Turkey } \\
\text { participated in the study. In order to collect data Leadership Style Scale and Humor Behavior Scale } \\
\text { were used. }\end{array}$ \\
\hline $\begin{array}{l}\text { Article Classification: } \\
\text { Research Article }\end{array}$ & $\begin{array}{l}\text { Findings - The findings of the study revealed that the subordinates working for different } \\
\text { institutions mostly think that their managers are transactional leaders. In addition, the results of } \\
\text { hierarchical multiple regression analysis indicated that humor types predict leadership styles at } \\
\text { different levels. }\end{array}$ \\
\hline & $\begin{array}{l}\text { Discussion - The results of this study revealed that leadership styles differ depending on the type } \\
\text { of organization. It can be argued that most of the subordinates in the organizations where the } \\
\text { managers are appointed believes that their managers have the qualities of a transactional leader. }\end{array}$ \\
\hline
\end{tabular}

\section{Introduction}

Humor could act as a therapeutic agent for the employees by creating an entertaining environment. It is also considered as a valuable administrative tool to increase production and workers' productivity (Avolio et al., 1999:220). Managers, school principals or teachers, whose job description include some kind of management qualities, take advantage of humor to ease the interpersonal communication (Rizzo et al., 1999:362). To this end, the humor used by the administrators, in the workplace where the individuals spend most of their time, is associated with their leadership qualities (Bass \& Stogdill, 1990:130; Shamir, 1995:28). According to Napier and Gershenfeld (1993:129) 98\% of executive managers nominate candidates for a leadership position with a good sense of humor. Crawford (1994:57) stresses that humor is the most-promising and least understood communication strategy used by the leaders. Although ignored until recently, because of its administrative qualities, the relationship between sense of humor and leadership style has become a topic of interest for the researchers (Decker \& Rotondo, 2001:456; Goswami et al., 2016:1086; Holmes \& Marra, 2006:132-133; Priest \& Swain, 2002:185; Romero \& Cruthirds, 2006:65).

Although the researchers believe that the concept of humor may contribute to the management (Bass \& Stogdill, 1990:132; Duncan et al., 1990:254; Shamir, 1995:24), the studies are mostly based on the views of managers and there are no studies regarding the predictive power of humor types in explaining leadership styles from the viewpoint of employees.

\section{Leadership}

Leadership has been studied extensively in a variety of contexts. The results revealed that leadership is an important component of all kinds of organizations and the managers should have the qualities of an effective

\section{Önerilen Atıf/ Suggested Citation}

Ergün, M., Akcaoğlu, M.Ö. (2020). Predictive Power of Humor Types in Explaining Leadership Styles in Different Organizations, Journal of Business Research-Turk, 12 (1), 921-937. 


\section{Ergün - M. Ö. Akcaoğlu 12/1 (2020) 921-937}

leader (Amanchukwu et al., 2015:8; Bowers, 2015:6; Martin, 2015:1316). The researchers in Turkey also carried out similar studies and tried to define leadership and its relation to some variables (Akman et al., 2015:140; Bakan et al., 2015:214; Cansoy \& Polatcan, 2018:276; Ercan \& Sığrı, 2015:95).

Upon examining the studies conducted in the past, it is observed that leadership is categorized under four different styles; charismatic, transformational, paternalist and transactional (Downton, 1973:274; House, 1976:5; Shaw, 1955:127). Charismatic leadership style was developed by House (1976:5). The word charisma was first used to define a special ability some people have to do an extraordinary task (Potts, 2009:14). Weber (1947:329) defined the concept as a personality trait providing an individual with exceptional abilities and stressed that only very few people has this kind of innate ability. According to charismatic leadership theory, leaders behave in a special way to create an effect on their subordinates (Northouse, 2013:188). Charismatic leaders are important but they cannot always be profitable for the organizations. Because these leaders are power oriented and this makes them insensitive, self-seeking and authoritarian (Yukl, 2010:294).

Transformational leadership, on the other hand, first put forward by Downton (1973) and reformulated by James MacGregor in 1978 (Akiş, 2004:35-36). Transformational leadership is a process in which individuals transform and change. It is about senses, values, ethics, standards and long-term goals. Transformational leader evaluates the motives of his/her subordinates, meets their needs and treats each of his/her subordinates as an individual. These leaders have the ability to take the subordinates beyond their capacities and transformational leadership is generally in cooperation with charismatic and visionary leadership. Transformational leadership as an inclusive approach can be used to define some simple efforts to influence the subordinates and some comprehensive efforts to affect whole organizations and culture (Northouse, 2013:185-186).

The third style, the paternalistic style, considers individuals as though they were separated from the work they are doing and paternalistic leaders are characterized as being "fatherly" or "motherly" toward their subordinates; view their organization as a "family"; do not involve others in the decision making process and awards submissiveness (Northouse, 2013:77). In addition, paternalist leadership, encompasses power, discipline and authority with paternalistic benevolence and ethical honesty (Türesin \& Köse, 2015:31). It is the intersection point of authoritarianism, benevolence, and moral leadership styles (Farh \& Cheng, 2000:124). Paternalist leaders consider the protection of their subordinates as a responsibility in order to gain their trust and loyalty (Ma et al., 2013:8-9). According to a classification based on geographic location, paternalistic style is still widespread in such cultures as the Middle East, Pacific Asia, and Latin America (Martinez, 2003:235; Pellegrini \& Scandura, 2006:265). Because of this, for the Western scholars it is difficult to understand paternalist leadership (Aycan, 2006:451).

Transactional leadership requires the protection and maintenance of status quo. In this style the subordinates are awarded immediately when they complete the task given by the leader (Locke, 1999:5). The leader, after explaining how to achieve a goal based on the personal needs of the subordinates, stands aside and does not intervene in the process till the goal is accomplished (Bertocci, 2009:49). Promising a premium upon reaching the goal or giving a grade to students when they finish their homework can be examples of such leadership (Northouse, 2013:186).

\section{The concept of humor and its relation to management}

The use of humor, defined as different, extra-ordinary, creative, innovative and motivating factor, is an important factor for the operability and development of organizations. Therefore, managers should have a good sense of humor besides their leadership skills (Csikszentmihalyi, 1996:225). A great deal of studies examined the relation between humor and leadership (Holmes \& Marra, 2006:132-133; Jones \& Bear, 2018:199; Pundt \& Venz, 2017:89; Recepoğlu, 2011:47; Recepoğlu \& Özdemir, 2012:25; Yang et al., 2017:1470:; Yirci et al., 2016:2480).

Studies related to humor goes back to Ancient Greece; however, the studies relating humor to other psychological constructs started to be carried out in the late 19th century (Goldstein, 1976:104). Goldstein (1976:105) investigated the development of scientific studies related to humor under three phases. The first phase, before developing or testing a theory, till the 1940s included the relational or observational studies regarding humor and laughter. During the second phase, also called the psychoanalytic phase, researchers attempted to explain humor through Freudian psychoanalytic theory. Until recently, most of the articles 


\section{Ergün - M. Ö. Akcaoğlu 12/1 (2020) 921-937}

related to humor or laughter was based on this second phase. The third phase of humor studies imply the cognitive components of humor. This period is based on Piaget's cognitive/constructivist approach.

Although the definition and development of humor were made, there are very few scientific studies about humor descriptions (Crawford, 1994:57). According to Meyer (1990:76) the reason is that humor is a hard-tounderstand concept and is not appealing for many scholars. When the literature is reviewed, it is observed that some authors define humor as a verbal skill (Hudson, 1980:28; Mulkay, 1988:24), while some others stress the non-verbal qualities of humor (Meyer, 1990:76).

Sense of humor has been attracting the attention of researchers for a long time. Although humor is thought to be a unique and independent construct, the research studies carried out revealed that humor can be better understood through related abilities and characteristics (Vernon et al., 2008:44). One of the constructs that humor can be related is leadership. Effective use of humor can increase the efficiency of leadership. Effective leaders may use humor to influence their subordinates, harm their rivals, protect themselves from criticism and so on (Lovaglia et al., 2008:21-22). For effective leaders, humor can also act as a catalyst while conveying unpleasant information. In addition, Dixon (1980:281) states that for leaders humor can help create a new and genuine perspective for the solution of a problem.

According to Martin (2007:211) there are four dimensions of humor; affiliative, self-enhancing, aggressive and self-defeating humor. In this study, humor classification developed by Cemaloğlu et al. (2012:694), based originally on Martin's four dimensions of humor, was used. For this reason, approving and productive social humor types mean affiliative and self-enhancing humor; aggressive and self-defeating humor mean ironic humor.

Affiliative humor involves saying funny things and telling jokes in order to reduce tension and improve interpersonal relationships and cohesiveness. Self-enhancing humor is a broader concept, it is a way of seeing life from a humorous point of view and finding an element of amusement when somebody confronts a problem or a stressful event. These two types are considered healthy or adaptive types. On the other hand, aggressive humor is about using humor to criticize or manipulate others. The fourth type of humor encompasses the use of humor for amusing others at one's own expense. In this type, an individual makes fun of himself or herself in order to gain acceptance, attention and approval of others.

\section{Humor and leadership}

Effective leaders have a good sense of humor and can use humor efficiently (Conger, 1989:119). In addition leaders may use humor to establish inter-group identity, develop harmony and sense of attachment, remove individual differences in terms of needs and wishes, promote innovative thinking, get rid of the contradictions regarding logic and beliefs (Duncan, 1982:138; Martin \& Lefcourt, 1983:1315; Ziv, 1990:334). According to Kahn (1989:47), humor is an important element in finding out different explanations to the events or situations, it also lets individuals step back psychologically and adopt a different point of view than the usual.

Although humor did not have an important role in leadership research until recently, it seems that the relations between the two constructs is promising for future research (Crawford, 1994:57). There are some studies explaining the relationship between humor and leadership (Bass \& Stogdill, 1990:70; Clouse \& Spurgeon, 1995:4; Shamir, 1995:24) and the effect of humor used by the leaders on subordinates (Goldstein, 1976:107; Hogan et al., 1994:13).

Leaders' use of humor can affect the performance of subordinates positively (Avolio et al., 1999:222). When a leader uses humor to solve problem, the subordinates can develop a new perspective and find or create solutions to the problem (Arendt, 2009:104). In addition, leaders' use of humor can increase subordinates' attachment to the organization, their performance at work (Avolio et al., 1999:223; Decker \& Rotondo, 2001:451; Hof et al., 1996:68; Katz, 1996:378), lower subordinates' stress level (Abel, 2002:367) and create a positive effect on the acceptance of change (Meliones, 2000:5). Although humor has "the potential to contribute to management and organizational behavior" (Duncan et al., 1990:255), the studies are mainly about the relation between use of humor and leadership style (Avolio et al., 1999:222; Smith \& Khojasteh, 2014:73). For instance, the study carried out by Avolio et al. (1999:222) revealed that humor used by the leaders with transformational leadership style have a positive effect on the performance of individuals and organization as a whole. The departments with transformational leaders using humor reached higher goals compared to the departments with leaders using less humor. These results signal that humor can help boost the performance of subordinates if used properly by the leaders. 


\section{Ergün - M. Ö. Akcaoğlu 12/1 (2020) 921-937}

The research studies also revealed that humor promotes creative thinking, finding revolutionary solutions and innovative offers (Holmes \& Marra, 2006:132-133) and there is a positive relation between humor used by the leaders and subordinates' creativity (Lussier et al., 2017:170; Şenol, 2013:36; Yue \& Hui, 2015:846). Therefore, leaders use humor as an effective way to support their subordinates creative performance and vitalize the environment (Amabile, 1996:101; Conger, 1989:119).

The use of humor can also be effective on subordinates' emotion and motivation levels. The studies carried out indicated that humor creates a more positive organizational culture (Clouse \& Spurgeon, 1995:21), strengthen the connection between group members (Duncan, 1982:137), stimulate individual and group creativity (Csikszentmihalyi, 1996; Murdock \& Ganim, 1993:59) and increase motivation (Crawford, 1994:57; Dienstbier, 1995:256; Lippitt, 1982:98).

As can be seen in the above mentioned studies, both leadership and humor have been extensively examined in terms of their relations with each other and with different variables. However, the predictive power of the concepts in explaining one another, especially from the viewpoint of subordinates, has not been investigated in the research studies. Determining the predictive power is of great importance because the findings may reveal the possible consequences of considering humor styles as a criterion during manager recruitment. On the other hand, taking the viewpoints of the subordinates into consideration can help eliminate the subjective perspective when the individuals evaluate their own personal features.

\section{Purpose of the study}

According to Çelik (2004:188) a manager coordinates the behavior of staff in the direction of institutional goals. A leader, on the other hand, is a person followed by a group of individuals to realize their personal and group goals and behave in the direction of his/her orders and instructions (Ertürk, 2000:124; Koçel, 2001:423). Based on the definitions made by researchers, there are important differences between a manager and a leader (Cemaloğlu, 2013:131; Covey, 2005:144; Göka, 2009:15-88; Keçecioğlu, 1998:10; Sezgin, 2013:44). A manager mostly focuses on organization, stability, staffing and control; on the other hand, a leader concentrates on producing change and mobility and has the ability to motivate and inspire the individuals. The studies carried out implies that when humor is used effectively, it can ease the management process and has a direct positive effect on the performance (Avolio et al., 1999:223; Csikszentmihalyi, 1996; Duncan, 1982:137; Gruner, 1997:55; Malone, 1980:358). Therefore, predicting the leadership style based on the humor type used can help realize the goals of the organization. To this end, the purpose of this study is to examine the humor type used by the leaders and try to predict the leadership style under paternalistic, charismatic, transactional and transformational dimensions from the viewpoint of subordinates. In line with the aims, the study investigated the following research questions.

1. Do the subordinates' views regarding the type of their leaders differ regarding the institutions, the position of the staff and gender?

2. What type of humor do the managers use based on their leadership style?

3. Do the type of humor predict leadership style of the managers?

\section{Method}

\section{Research Design and Study Group}

In this study, a descriptive research design was used to find out whether the subordinates' views regarding the type of their leaders differ and the type of humor predict leadership style of the managers. In descriptive research, the situations are examined as they are without any intervention (Fraenkel \& Wallen, 2007:691).

Since the purpose of generalization was not pursued within the scope of the research, no population-sampling method was used and data were collected from the study group. The study was conducted in a city located in Black Sea Region, Turkey. 225 workers (102 females and 123 males) from six different sectors participated in the study. Detailed information regarding the distribution of the sample based on different variables is presented in Table 1. 
M. Ergün - M. Ö. Akcaoğlu 12/1 (2020) 921-937

Table 1. Distribution of the sample based on different variables

\begin{tabular}{llcc}
\hline Variable Type & Variable & $\mathrm{N}$ & $\%$ \\
\hline \multirow{2}{*}{ Gender } & Female & 102 & 45.2 \\
& Male & 123 & 54.8 \\
\hline \multirow{4}{*}{ Type of Organization } & Municipality and Provincial Special Administration & 30 & 11.0 \\
& University & 33 & 15.1 \\
& Health & 36 & 16.4 \\
& Education and Culture & 27 & 12.3 \\
& Governorship and subsidiaries & 75 & 34.2 \\
& Social Security Institution & 24 & 11.0 \\
\multirow{3}{*}{ Status } & Civil servant & 141 & 63.0 \\
& Worker & 57 & 26.0 \\
& Sub-Contracted Worker & 27 & 11.0 \\
\hline
\end{tabular}

\section{Data Collection Tools}

In the study, two different scales, Leadership Style Scale and Humor Behavior Scale, were used to collect data. The two scales were chosen because of their convenience for the sample and high reliability and validity coefficients. In addition, both scales were widely used in similar studies in different cultures.

The first scale was "Leadership Style Scale" adapted into Turkish by Öztop (2008) from different leadership style scales. Öztop (2008:73) used Conger and Kanungo (1987:637)'s Charisma Scale and Questionnaire for Charismatic Leadership in Organizations (CLIO) to determine charismatic leadership. For paternalistic leadership, Voich (1995:48)'s paternalistic leadership scale was used. In addition, House and Dessler (1974:32)'s instrumental leadership scale and Carless et al., (2000:393)'s Transformational Leadership Scale (GTL) were used. The Cronbach Alpha values of the adapted scale were 0.83 for instrumental leadership, 0.88 for paternalistic leadership, 0.91 for transformational leadership and 0.90 for charismatic leadership (Öztop, 2008:75). Exploratory factor analysis (EFA) was conducted with 27 items under four sub-dimensions during the adaptation phase. The results of EFA revealed a four-dimension structure with 23 items (4 items were omitted based on the analysis) on a 5 point Likert scale. Table 2 shows the number of items in each subdimension, the score range and total variance explained (TVE) by each sub-dimension.

Table 2. The results for Leadership Style Scale regarding the number of items, the score range and total variance explained

\begin{tabular}{lccc}
\hline Factor & Number of Items & Score Range & TVE \\
\hline Instrumental Leadership & 4 & $4-20$ & $67.36 \%$ \\
Paternalistic Leadership & 5 & $5-25$ & $67.98 \%$ \\
Transformational Leadership & 7 & $7-35$ & $66.72 \%$ \\
Charismatic Leadership & 7 & $7-35$ & $57.97 \%$ \\
\hline
\end{tabular}

In order to determine managers' humor styles "Humor Behavior Scale", developed by Cemaloğlu et al. (2012:703), was used in the study. EFA results indicated that the 5 point Likert scale consisted of five dimensions; ironic humor (.94), productive social humor (.92), approving humor (.86), disapproving humor (.85) and unhumorous style (.89). The Cronbach Alpha value for the whole scale was found to be .92 . The number of items in each sub-dimension, the score range and total variance explained by each sub-dimensions are presented in Table 3.

Table 3. The results for Humor Behavior Scale regarding the number of items, the score range and total variance explained

\begin{tabular}{lccc}
\hline Factor & Number of Items & Score Range & TVE \\
\hline Unhumorous Style & 3 & $3-15$ & $8.89 \%$ \\
Disapproving Humor & 5 & $5-25$ & $10.53 \%$ \\
Approving Humor & 5 & $5-25$ & $12.53 \%$ \\
Productive Social Humor & 9 & $9-45$ & $18.22 \%$ \\
Ironic Humor & 8 & $8-40$ & $19.92 \%$ \\
\hline
\end{tabular}




\section{Procedures}

The scale was administered to the participants by the researchers during the rest breaks at workplaces. The subjects completed the surveys in reference to the chief executive officer they work with. In addition, they were informed about the scope of the research and that there were no right or wrong answers. Finally, it was emphasized that the responses to the survey would remain anonymous.

\section{Data Analysis}

In this study, to answer the research questions descriptive analysis, t-test, bivariate correlation tests and hierarchical multiple regression analysis were conducted and Statistical software package SPSS for Windows version 22 was used for all analyses. Before conducting hierarchical multiple regression analysis, kurtosis and skewness coefficients, VIF, tolerance and Mahalanobis distance values were examined to control whether these values met the assumptions of the analysis.

\section{Preliminary Analysis}

The results of normality tests revealed that the skewness and the kurtosis coefficients were between the criterion value of \pm 1 and the data showed normal distribution. In addition, VIF and tolerance values were checked. The highest VIF value should be lower than 10 and tolerance value should be higher .20 (Field, 2013:574). In this study, the VIF value was smaller than the criterion value of 10 (VIF=1.25-1.66) and tolerance values were bigger than the criterion value of $0.2(.60-.80)$. When Mahalanobis distance values were examined, it was observed that the values of six participants were out of required ranges and these values were not added to the analysis. Thus, it was observed that the basic assumptions of regression analysis were met. In order to check the relationship between leadership style and humor perception, correlation coefficients were examined.

Another assumption for performing hierarchical multiple regression is that there is no high correlation between variables. Evans (1996:146) stated that for the value of $\mathrm{r} .00-.19$ is a "very weak" correlation, .20-.39 is a "weak" correlation, .40-.59 is a "moderate" correlation, .60-.79 is a "strong" correlation and .80-1.0 is a "very strong" correlation. When the relationship between leadership types and types of humor is analyzed based on Pearson's correlation coefficient, it was revealed that the $\mathrm{r}$ values ranged from -.33 to .38 mostly indicating a weak correlation between the variables. Moreover, the scatter plot diagram revealed a linear correlation.

\section{Findings}

When Table 4 is examined, it can be seen that the subordinates working for the municipality and provincial special administration mostly consider their manager as charismatic leaders $(50 \%)$. The subordinates working at the university view their manager as paternalistic leader $(45.5 \%)$. On the other hand, the subordinates working for health (63.9\%), education and culture (66.7\%), governorship and its subsidiaries (50.7\%) and social security $(75 \%)$ institutions mostly think that their managers are transactional leaders.

Table 4. Distribution of leadership style based on the organizations

\begin{tabular}{|c|c|c|c|c|c|c|}
\hline \multirow[b]{2}{*}{ Organization } & \multicolumn{6}{|c|}{ Leadership Style } \\
\hline & & Paternalistic & Charismatic & Transactional & $\begin{array}{c}\text { Transformation } \bar{c} \\
1\end{array}$ & Total \\
\hline \multirow{2}{*}{$\begin{array}{l}\text { Municipality and } \\
\text { Provincial Special } \\
\text { Administration }\end{array}$} & $\mathrm{n}$ & 3 & 15 & 9 & 3 & 30 \\
\hline & $\%$ & 10.0 & 50.0 & 30.0 & 10.0 & 100.0 \\
\hline \multirow{2}{*}{ University } & $\mathrm{n}$ & 15 & 3 & 8 & 7 & 33 \\
\hline & $\%$ & 45.5 & 9.1 & 24.2 & 21.2 & 100.0 \\
\hline \multirow{2}{*}{ Health } & $\mathrm{n}$ & 0 & 2 & 23 & 11 & 36 \\
\hline & $\%$ & 0.0 & 5.6 & 63.9 & 30.6 & 100.0 \\
\hline \multirow{2}{*}{ Education and Culture } & $\mathrm{n}$ & 2 & 3 & 18 & 4 & 27 \\
\hline & $\%$ & 7.4 & 11.1 & 66.7 & 14.8 & 100.0 \\
\hline \multirow{2}{*}{$\begin{array}{l}\text { Governorship and } \\
\text { subsidiaries }\end{array}$} & $\mathrm{n}$ & 18 & 7 & 38 & 12 & 75 \\
\hline & $\%$ & 24.0 & 9.3 & 50.7 & 16.0 & 100.0 \\
\hline Security & $\mathrm{n}$ & 3 & 0 & 18 & 3 & 24 \\
\hline Institution & $\%$ & 12.5 & 0.0 & 75.0 & 12.5 & 100.0 \\
\hline
\end{tabular}




\section{Ergün - M. Ö. Akcaoğlu 12/1 (2020) 921-937}

When the mean scores of leadership styles based on subordinates' positions are examined, it was observed that the mean score for paternalistic leadership was between $\bar{x}=14.11$ and $\bar{x}=15.38$, for transactional leadership between $\bar{x}=15.11$ and $\bar{x}=17.00$, for charismatic leadership between $\bar{x} 29.37$ and $\bar{x} 34.78$ and for transformational leadership between $\bar{x}=18.53$ and $\bar{x}=21.89$.

Table 5. Leadership style perception differences based on gender

\begin{tabular}{lcccccccc}
\hline Leadership Style & Gender & $\mathrm{N}$ & $\overline{\mathrm{x}}$ & $\mathrm{Ss}$ & $\mathrm{t}$ & $\mathrm{Sd}$ & $\begin{array}{c}\text { Mean } \\
\text { Difference }\end{array}$ & $\mathrm{p}$ \\
\hline Paternalistic & Female & 102 & 14.35 & 4.325 & -1.30 & 223 & -.79 & .19 \\
& Male & 123 & 15.15 & 4.723 & & & & \\
Charismatic & Female & 102 & 31.53 & 7.182 & 1.06 & 219.24 & 1.21 & .29 \\
& Male & 123 & 30.32 & 9.911 & & & & .23 \\
Transactional & Female & 102 & 16.06 & 2.789 & 1.20 & 223 & .43 & .04 \\
Transformational & Male & 123 & 15.63 & 2.516 & & & \\
\hline
\end{tabular}

An independent sample t-test was used to determine whether the employees' views regarding their supervisors' leadership styles differ in terms of gender (Table 5). According to the results of the analysis, there was no statistically significant difference between paternalistic, charismatic and transactional leadership styles and gender. On the other hand, the results indicated that there was a statistically significant difference between female and male subordinates in terms of transformational leadership ( $t(S d=223)=2.01, p<.005$ ). Female subordinates consider their managers more transformational than their male counterparts.

Table 6. Mean scores of humor types based on leadership styles

\begin{tabular}{llccc}
\hline Humor & Leadership & $\mathrm{N}$ & $\overline{\mathrm{x}}$ & Ss \\
\hline \multirow{4}{*}{ Ironic } & Paternalistic & 41 & 15.59 & 8.02 \\
& Charismatic & 30 & 19.60 & 9.64 \\
& Transactional & 114 & 15.96 & 7.96 \\
& Transformational & 40 & 11.68 & 5.65 \\
\hline \multirow{4}{*}{ Unhumorous } & Paternalistic & 41 & 7.71 & 2.52 \\
& Charismatic & 30 & 7.80 & 3.38 \\
& Transactional & 114 & 8.93 & 3.32 \\
& Transformational & 40 & 7.75 & 2.98 \\
\hline \multirow{4}{*}{ Aisapproving } & Paternalistic & 41 & 9.98 & 4.56 \\
& Charismatic & 30 & 12.30 & 4.54 \\
& Transactional & 114 & 13.42 & 5.26 \\
& Transformational & 40 & 9.98 & 4.19 \\
\hline \multirow{3}{*}{ Productive Social } & Paternalistic & 41 & 14.44 & 3.59 \\
& Charismatic & 30 & 15.57 & 3.33 \\
& Transactional & 114 & 11.95 & 3.78 \\
& Transformational & 40 & 15.08 & 3.99 \\
\hline & Paternalistic & 41 & 25.07 & 7.20 \\
& Charismatic & 30 & 25.43 & 6.65 \\
& Transactional & 114 & 16.11 & 6.73 \\
& Transformational & 40 & 21.38 & 7.25 \\
\hline
\end{tabular}

When Table 6, which is about the humor types based on leadership styles, is examined, it was observed that ironic $(\bar{x}=19.60)$, approving $(\bar{x}=15.57)$ and productive social $(\bar{x}=25.43)$ humor types are mostly used by charismatic leaders. Disapproving humor was mostly used by transactional leaders $(\bar{x}=13.42)$. On the other hand, of all the humor types, unhumorous humor had the lowest mean scores. 
Table 7. Normality of the distribution based on humor types

\begin{tabular}{lccccc} 
& $\begin{array}{c}\text { Non- } \\
\text { Humorous }\end{array}$ & $\begin{array}{c}\text { Rejective } \\
\text { Humor }\end{array}$ & $\begin{array}{c}\text { Approver } \\
\text { Humor }\end{array}$ & $\begin{array}{c}\text { Productive Social } \\
\text { Humor }\end{array}$ & $\begin{array}{c}\text { Ironic } \\
\text { Humor }\end{array}$ \\
\hline Mean & 8.44 & 11.99 & 13.48 & 20.07 & 15.36 \\
Median & 8.00 & 11.00 & 14.00 & 19.00 & 12.00 \\
Mod & 6 & 10 & 14 & 27 & 8 \\
Skewness & .37 & .43 & .18 & .29 & .98 \\
Kurtosis & -.41 & -.54 & -.13 & -1.14 & .23 \\
\hline
\end{tabular}

Table 7 presents descriptive analysis regarding the sub-dimensions of humor types scale. The results revealed that productive social humor has the highest average score $(\mathrm{M}=20.07)$ and non-humorous type has the lowest average score $(\mathrm{M}=8.44)$. In addition, the skewness values are between -1 and +1 , kurtosis values are between -2 and +2 which indicates normal distribution (Bulmer, 1979:124; Cramer, 1997:146; George \& Mallery, 2010:58; Hahs-Vaughn \& Lomax, 2013:169).

Table 8. The results of hierarchical multiple regression between paternalistic leadership style and humor types

\begin{tabular}{|c|c|c|c|c|c|c|}
\hline Variable & $\beta$ & $\mathrm{t}$ & $\mathrm{sr}^{2}$ & $\mathrm{R}$ & $\mathrm{R}^{2}$ & $\Delta \mathrm{R}^{2}$ \\
\hline Step 1 & & & & .22 & .05 & .05 \\
\hline Non-Humorous & -.22 & $-3.38^{* *}$ & -.22 & & & \\
\hline Step 2 & & & & .38 & .14 & .09 \\
\hline Non-Humorous & -.14 & $-2.30^{*}$ & -.15 & & & \\
\hline Approver Humor & .32 & $4.95^{* * *}$ & .31 & & & \\
\hline Step 3 & & & & .52 & .27 & .07 \\
\hline Non-Humorous & -.09 & -1.51 & -.10 & & & \\
\hline Approver Humor & -.09 & 1.41 & -.09 & & & \\
\hline Productive Social Humor & .42 & $6.09^{* * *}$ & .38 & & & \\
\hline Step 4 & & & & .55 & .31 & .04 \\
\hline Non-Humorous & -.03 & -.49 & -.03 & & & \\
\hline Approver Humor & .05 & .80 & -.05 & & & \\
\hline Productive Social Humor & .52 & $7.08^{* * *}$ & .43 & & & \\
\hline Ironic Humor & -.21 & $-3.42^{* *}$ & -.22 & & & \\
\hline Step 5 & & & & .60 & .36 & .05 \\
\hline Non-Humorous & .15 & $2.11^{*}$ & .14 & & & \\
\hline Approver Humor & .06 & .97 & .06 & & & \\
\hline Productive Social Humor & .51 & $7.24^{* * *}$ & .44 & & & \\
\hline Ironic Humor & -.10 & -1.63 & -.11 & & & \\
\hline Rejective Humor & -.33 & $-4.40^{* * *}$ & -.28 & & & \\
\hline $\mathrm{N}=219 \quad{ }^{*} \mathrm{p}<.05$ & ${ }^{* *} \mathrm{p}<.01$ & ${ }^{* * * *} \mathrm{p}<.001$ & & & & \\
\hline
\end{tabular}

In Table 8, the results of hierarchical multiple regression between paternalistic leadership style and humor types are presented. The hierarchical multiple regression revealed that at stage one, Non-humorous type contributed significantly to the regression model, $\mathrm{F}(1-217)=11.485, \mathrm{p}<.01)$ and accounted for $4.6 \%$ of the variation in the paternalist leadership. The attachment variable (approver humor) explained an additional $13.9 \%$ of variation in the paternalist leadership and this change in $\mathrm{R}^{2}$ was significant, $\mathrm{F}(2-216)=18.638, \mathrm{p}<.001$. Adding Productive Social Humor to the regression model explained an additional $26.3 \%$ of the variation in the paternalist leadership and this change in $\mathrm{R}^{2}$ was also significant, $\mathrm{F}(3-215)=26.903, \mathrm{p}<.001$. The hierarchical multiple regression revealed that stage four contributed significantly to the regression model, $\mathrm{F}(4-214)=$ $24.122, \mathrm{p}<.001$ ) and accounted for $29.8 \%$ of the variation in the paternalist leadership. Finally, the addition of Rejective Humor to the regression model explained an additional $35.3 \%$ of the variation in the paternalist 
leadership and this change in $\mathrm{R}^{2}$ square was also significant, $\mathrm{F}(5-213)=24.838, \mathrm{p}<.001$. When all five independent variables were included in stage five of the regression model, neither approver humor nor ironic humor were significant predictors of paternalist leadership. The most important predictor of paternalist leadership was productive social humor. Together the five independent variables accounted for $35.3 \%$ of the variance in the paternalist leadership.

Table 9. The results of hierarchical multiple regression between charismatic leadership style and humor types

\begin{tabular}{|c|c|c|c|c|c|c|}
\hline Variable & $\beta$ & $t$ & $\mathrm{sr}^{2}$ & $\mathrm{R}$ & $\mathrm{R}^{2}$ & $\Delta \mathrm{R}^{2}$ \\
\hline Step 1 & & & & .185 & .034 & .034 \\
\hline Non-Humorous & -.185 & $-2.765^{* *}$ & -.185 & & & \\
\hline Step 2 & & & & .381 & .145 & .111 \\
\hline Non-Humorous & -.104 & -1.611 & -.109 & & & \\
\hline Approver Humor & .343 & $5.294^{* * *}$ & .339 & & & \\
\hline Step 3 & & & & .431 & .186 & .041 \\
\hline Non-Humorous & -.072 & -1.117 & -.076 & & & \\
\hline Approver Humor & .217 & $2.927^{* *}$ & .196 & & & \\
\hline Productive Social Humor & .244 & $3.281^{* *}$ & .218 & & & \\
\hline Step 4 & & & & .431 & .186 & .000 \\
\hline Non-Humorous & -.067 & -.998 & -.068 & & & \\
\hline Approver Humor & .213 & $2.830^{* *}$ & .190 & & & \\
\hline Productive Social Humor & .251 & $3.120^{* *}$ & .209 & & & \\
\hline Ironic Humor & -.016 & -.236 & -.016 & & & \\
\hline Step 5 & & & & .444 & .197 & .011 \\
\hline Non-Humorous & .014 & .172 & .012 & & & \\
\hline Approver Humor & .217 & $2.894^{* *}$ & .194 & & & \\
\hline Productive Social Humor & .247 & $3.082^{* *}$ & .207 & & & \\
\hline Ironic Humor & .032 & .434 & .030 & & & \\
\hline \multirow[t]{2}{*}{ Rejective Humor } & -.147 & -1.727 & -.118 & & & \\
\hline & $\mathrm{N}=219$ & ${ }^{*} \mathrm{p}<.05$ & ${ }^{* *} p<.01$ & $* * * p<.001$ & & \\
\hline
\end{tabular}

Table 9 presents the results of hierarchical multiple regression between charismatic leadership style and humor types. The hierarchical multiple regression revealed that at Stage one, Non-humorous type contributed significantly to the regression model, $\mathrm{F}(1-217)=7.648, \mathrm{p}<.01)$ and accounted for $3 \%$ of the variation in the charismatic leadership. The Attachment variables explained an additional $13.7 \%$ of variation in the charismatic leadership and this change in $\mathrm{R}^{2}$ was significant, $\mathrm{F}(2-216)=18.313, \mathrm{p}<.01$. Adding Productive Social Humor to the regression model explained an additional $17.4 \%$ of the variation in the charismatic leadership and this change in $\mathrm{R}^{2}$ was significant, $\mathrm{F}(3-215)=16.348, \mathrm{p}<.001$. The hierarchical multiple regression revealed that Stage four contributed significantly to the regression model, $F(4-214)=12.221, \mathrm{p}<.001)$ and accounted for $17.1 \%$ of the variation in the charismatic leadership. Finally, the addition of Rejective Humor to the regression model explained an additional $17.8 \%$ of the variation in the charismatic leadership and this change in $\mathrm{R}^{2}$ square was also significant, $\mathrm{F}(5-213)=10.464, \mathrm{p}<.001$. When all five independent variables were included in stage five of the regression model, Non-Humorous and ironic humor and rejective humor weren't significant predictors of charismatic leadership. The most important predictor of charismatic leadership was Productive social humor. Together the five independent variables accounted for $19.7 \%$ of the variance in the charismatic leadership. 
M. Ergün - M. Ö. Akcaoğlu 12/1 (2020) 921-937

Table 10. The results of hierarchical multiple regression between transactional leadership style and humor types

\begin{tabular}{|c|c|c|c|c|c|c|}
\hline Variable & $\beta$ & $\mathrm{t}$ & $\mathrm{sr}^{2}$ & $\mathrm{R}$ & $\mathrm{R}^{2}$ & $\Delta \mathrm{R}^{2}$ \\
\hline Step 1 & & & & .054 & .003 & .003 \\
\hline Non-Humorous & .054 & .794 & .054 & & & \\
\hline Step 2 & & & & .334 & .112 & .109 \\
\hline Non-Humorous & -.026 & -.387 & -.026 & & & \\
\hline Approver Humor & -.340 & -5.148 & $-.331^{* * *}$ & & & \\
\hline Step 3 & & & & .509 & .259 & .147 \\
\hline Non-Humorous & -.088 & -1.435 & -.097 & & & \\
\hline Approver Humor & -.100 & -1.418 & -.096 & & & \\
\hline Productive Social Humor & -.464 & -6.540 & $-.407^{* * *}$ & & & \\
\hline Step 4 & & & & .523 & .274 & .015 \\
\hline Non-Humorous & -.126 & -1.988 & $-.135^{*}$ & & & \\
\hline Approver Humor & -.073 & -1.026 & -.070 & & & \\
\hline Productive Social Humor & -.524 & -6.891 & $-.426^{* * *}$ & & & \\
\hline Ironic Humor & .135 & 2.086 & $.141^{*}$ & & & \\
\hline Step 5 & & & & .525 & .275 & .001 \\
\hline Non-Humorous & -.097 & -1.248 & -.085 & & & \\
\hline Approver Humor & -.072 & -1.005 & -.069 & & & \\
\hline Productive Social Humor & -.526 & -6.898 & $-.427^{* * *}$ & & & \\
\hline Ironic Humor & .152 & 2.177 & $.148^{*}$ & & & \\
\hline \multirow[t]{2}{*}{ Rejective Humor } & -.053 & -.656 & -.045 & & & \\
\hline & $\mathrm{N}=219$ & & ${ }^{* *} \mathrm{p}<.01$ & ${ }^{* * *} p<.001$ & & \\
\hline
\end{tabular}

In Table 10, the results of hierarchical multiple regression between transactional leadership style and humor types are demonstrated. Hierarchical multiple regression revealed that the non-humorous in the stage one did not make a significant contribution to the regression model, F (1-217) $=.635, \mathrm{p}>.05)$ and accounted for $0.2 \%$ of the variation in the Transactional leadership. The Attachment variables explained an additional 10.4\% of variation in the Transactional leadership and this change in $R^{2}$ was significant, $F(2-216)=13.603, p<.001$. Adding Productive Social Humor to the regression model explained an additional $24.9 \%$ of the variation in the Transactional leadership and this change in $\mathrm{R}^{2}$ was significant, $\mathrm{F}(3-215)=25.081, \mathrm{p}<.001$. The hierarchical multiple regression revealed that Stage four contributed significantly to the regression model, F (4-214) = $20.192, \mathrm{p}<.001$ ) and accounted for $26.0 \%$ of the variation in the Transactional leadership. Finally, the addition of Rejective Humor to the regression model explained an additional $25.8 \%$ of the variation in the Transactional leadership and this change in $\mathrm{R}^{2}$ square was also significant, $\mathrm{F}(5-213)=16.196, \mathrm{p}<.001$. When all five independent variables were included in stage five of the regression model, Non-Humorous and Approver Humor and Rejective Humor were not significant predictors of Transactional leadership. The most important predictor of Transactional leadership was Productive social humor. Together the five independent variables accounted for $27.5 \%$ of the variance in the Transactional leadership.

Table 11. The results of hierarchical multiple regression between transformational leadership style and humor types

\begin{tabular}{|c|c|c|c|c|c|c|}
\hline Variable & $\beta$ & $\mathrm{t}$ & $\mathrm{sr}^{2}$ & $\mathrm{R}$ & $\mathrm{R}^{2}$ & $\Delta \mathrm{R}^{2}$ \\
\hline Step 1 & & & & .130 & .017 & .017 \\
\hline Non-Humorous & -.130 & -1.935 & -.130 & & & \\
\hline Step 2 & & & & .300 & .090 & .073 \\
\hline Non-Humorous & -.065 & -.974 & -.066 & & & \\
\hline Approver Humor & .278 & $4.166^{* * *}$ & .273 & & & \\
\hline Step 3 & & & & .308 & .095 & .005 \\
\hline Non-Humorous & -.054 & -.795 & -.054 & & & \\
\hline Approver Humor & .234 & $3.004^{* * *}$ & .201 & & & \\
\hline Productive Social Humor & .085 & 1.081 & .073 & & & \\
\hline
\end{tabular}




\begin{tabular}{lcccccc}
\hline Step 4 & & & & .457 & .208 & .113 \\
Non-Humorous & .053 & .795 & .054 & & & \\
Approver Humor & .160 & $2.145^{*}$ & .145 & & & \\
Productive Social Humor & .251 & $3.159^{* *}$ & .211 & & \\
Ironic Humor & -.373 & $-5.540^{* * *}$ & -.354 & & .009 \\
\hline Step 5 & & & & .466 & .217 & \\
Non-Humorous & .122 & 1.515 & .103 & & \\
Approver Humor & .163 & $2.196^{*}$ & .149 & & \\
Productive Social Humor & .247 & $3.122^{* *}$ & .209 & & \\
Ironic Humor & -.332 & $-4.575^{* * *}$ & -.299 & & \\
Rejective Humor & -.127 & -1.501 & -.102 & & \\
\hline & $\mathrm{N}=219$ & ${ }^{*} \mathrm{p}<.05$ & ${ }^{* *} \mathrm{p}<.01$ & ${ }^{* * *} \mathrm{p}<.001$ & & \\
\hline
\end{tabular}

The results of hierarchical multiple regression between transformational leadership style and humor types are presented in Table 11. The hierarchical multiple regression revealed that at Stage one, Non-humorous did not contributed significantly to the regression model, F $(1-217)=3.742, \mathrm{p}>.05)$ and accounted for $1.2 \%$ of the variation in the transformational leadership. The Attachment variables explained an additional $8.2 \%$ of variation in the transformational leadership and this change in $\mathrm{R}^{2}$ was significant, $\mathrm{F}(2-216)=10.691, \mathrm{p}<.001$. Adding Productive Social Humor to the regression model explained an additional $8.2 \%$ of the variation in the transformational leadership and this change in $\mathrm{R}^{2}$ was significant, $\mathrm{F}(3-215)=7.522$, $\mathrm{p}<.001$. The hierarchical multiple regression revealed that Stage four contributed significantly to the regression model, $\mathrm{F}(4-214)=$ 14.092, $\mathrm{p}<.001$ ) and accounted for $19.4 \%$ of the variation in the transformational leadership. Finally, the addition of Rejective Humor to the regression model explained an additional $19.8 \%$ of the variation in the transformational leadership and this change in $\mathrm{R}^{2}$ square was also significant, $\mathrm{F}(5-213)=11.791, \mathrm{p}<.001$. When all five independent variables were included in stage five of the regression model, neither Non-Humorous nor Rejective Humor were significant predictors of transformational leadership. The most important predictor of transformational leadership was Ironic Humor. Together the five independent variables accounted for $21.7 \%$ of the variance in the transformational leadership.

\section{Discussion and Conclusion}

Although there is a continuing interest in the relationship between leadership styles and humor types in the workplace, the number of studies examining the predictive power of humor on the leadership is limited. The researchers assert that there is no single recipe for being an effective leader (Goffee \& Jones, 2000:66; Higgs \& Rowland, 2001:62) and the relation between the leadership style of the managers and the field of the organization is crucial (Dulewicz \& Higgs, 2004:10). The results of this study revealed that leadership styles differ depending on the type of organization. It can be argued that most of the subordinates in the organizations where the managers are appointed believes that their managers have the qualities of a transactional leader. It is known that in Turkey, determining a manager varies based on the type organization; election or appointment. Accordingly, in the organizations, where the manager is elected, charismatic and paternalistic leadership styles come to the fore. It is possible that subordinates elect charismatic leaders because of their influence on others with their vision, self-confidence, courage, rhetoric and persuasion characteristics (House, 1976:4). Furthermore, the results indicated that elected managers also have paternalistic leadership style. Köksal (2011:119) contends that the leaders in the Eastern communities shows the qualities of a paternalistic leader. Paternalistic leaders behave like fathers to their subordinates, protecting, directing, guiding employees, as they would their children (Mussolino \& Calabrò, 2014:207). These type of leaders prefer a style in which discipline and authority are blended with helpfulness and moral honesty (Farh \& Cheng, 2000: 120; Hayek et al., 2010:375). On the other hand, the results disclosed that appointed managers adopt rewards as a tool to motivate their subordinates. Using a carrot-and-stick approach to manage the subordinates is the basic principle of transactional leadership (Singer \& Singer, 1990:390).

Upon analyzing the results regarding the perceptions of subordinates based on their position in the workplace, it was concluded that sub-contracted workers mostly identify their managers as transformational leaders. Transformational leaders focus on the link between the identities of the staff and organization's shared identity. Thus, the staff's intrinsic motivation and the quality of mutual relations boost (Jung, Chow, \& Wu, 


\section{Ergün - M. Ö. Akcaoğlu 12/1 (2020) 921-937}

2003:540). In such a country as Turkey, where it is hard to get a job, an individual might readily adopt the organizational culture and be transformed by the leader. To this end, Ören, Acar, and Kandemir (2016:180) assert that managers describe sub-contracted workers as insecure, off the books, non-standard and suitable for flexible working hours. This kind of view and the working conditions of sub-contracted workers implies that they are more inclined to transformation. Moreover, because sub-contracted workers have short-term contracts and the fear of losing their job, they might choose to establish good rapport with their managers in any situation and support them for the transformation efforts.

Even though there was no significant difference among the transactional, charismatic and paternalistic leadership styles with regard to gender, there was a statistically significant difference between female and male participants in terms of transformational leadership style. Female subordinates mostly perceive their leaders as transformational and so they view them as inspirational. Female workers' perception might stem from their emotional inclination because females are mostly regarded as more emotional (Briton \& Hall, 1995:89; Robinson \& Johnson, 1997:255; Timmers et al., 2003:60) and transformational leaders take advantage of emotions to motivate their subordinates and they are optimistic (Bass, 1998:56; Dubinsky et al., 1995:29). However, according to Dulewicz and Higgs (2005:120) there was no difference between female and male subordinates in terms of leadership style perceptions.

The results of hierarchical multiple regression between paternalistic leadership style and humor types revealed that each of the steps in the model significantly predicted paternalistic leadership and the most predictive step was the fifth step because it has the highest predicted R-squared (35.3\%). Moreover, in the fifth step, the most important predictor variable was social productive humor type. We can say that all the humor types added to the model are important variables to predict paternalistic leadership style. In other words, if the type humor used by a leader is known, we can estimate whether or not the leader has paternalistic leadership style $35.3 \%$. When relevant literature is reviewed, it was seen that although there are a lot of studies have focusing on various aspects of the topic such as the relationship between leadership style, the use of humor and individual and unit-level performance (Avolio et al., 1999:225), leader use of humor, transformational leadership and creative performance followers (Arendt, 2009:104; Lee, 2015:84) and transformational leadership style, leaders' positive humor and employees' positive emotions stronger (Goswami et al., 2016:1095), none of them deal with the predictive power of humor types in explaining leadership styles.

When the predictive power of humor types in explaining charismatic leadership style is analyzed through hierarchical multiple regression, it was seen that all five steps had significant predictive power. However, the fifth step, which included all humor types, has the highest predicted R-squared $(17.8 \%)$ and the most important predictor variable was social productive humor type. The results suggest that humor types can significantly predict charismatic leadership, although not high as in the case of paternalistic leadership style.

Hierarchical multiple regression analysis carried out to find out the predictive power of humor types in explaining transactional leadership style indicated that the final step of model has the highest predicted Rsquared (27.5\%). In this step, it was also revealed that transactional leaders do not prefer using social productive humor. In addition, it was observed that rejective humor does not contribute to the predictive power of the model when the fourth and fifth steps are examined. On the other hand, it can be said that humor types can predict the existence of transactional leadership style, but not as strong as paternalistic leadership style.

The results of hierarchical multiple regression between transformational leadership style and humor types revealed that the fifth step of the model predicted transformational leadership style $21.7 \%$. Moreover, social productive humor type was the most important predictor variable. To this end, it can be asserted that the managers with a sense of social productive humor are more likely to be transformational leaders. On the other hand, the results indicated that the less a leader use ironic humor the more likely that the leader is transformational.

In this study, it was found out that leadership styles differ based on the institution type and the type of humor used by the leader significantly predicts his or her leadership style. Furthermore, it can be claimed that the leadership styles change regarding the goals of institutions. Accordingly, we can state that in the appointment 
process of a manager to an institution, defining the leadership style and using it as a criterion may help realize the goals of the institution more effectively.

The results also showed that civil servants and workers perceive their managers as transactional leaders but sub-contracted workers view them as transformational leaders. In addition, contracted workers identify their managers more charismatic compared to the views of workers. Based on these findings it can be stated that managers' behaviors change depending on the status of the staff. Because of this, the differences regarding the behaviors of the managers against their subordinates could be investigated to reveal the causes of such behavior choices. When the findings are examined in terms of the gender variable, it was seen that gender is only significant when the leader is transformational. Whether the reason for this significant difference between the genders is emotional or not should also be researched.

According to the humor-related results of the study, we can assert that humor types differs based on the leadership styles. For this reason, during the appointment or selection process of a manager, determining the humor type used by the candidate may contribute the effective management process. However, the number studies regarding the predictive power of humor types in explaining leadership styles is scarce which limited the comparison of the findings of this study with other studies. Therefore, carrying out similar studies with samples from different cultures can make major contribution to the field of administration and humor studies.

\section{Limitations of the study}

In this study, a number of limitations can be listed. Initially, the sample of the study consists of the subordinates working in only one city in Turkey. Therefore, the results cannot be generalized to all populations and other cultures. In addition, the data were collected through self-report survey design which relies on the individual's sincerity.

\section{References}

Abel, M. H. (2002). Humor, stress, and coping strategies. Humor-International Journal of Humor Research, $15(4), 365-381$.

Akiş, Y., T., (2004). Türkiye'nin gerçek liderlik haritası. İstanbul: Alfa Basım Yayım Dağııım Ltd.

Akman, V., Hanoglu, M., \& Kızıl, C. (2015). Liderlik ile personel performansı arasındaki ilişki üzerine bir şirket incelemesi. Electronic Journal of Social Sciences, 14(52), 130-145.

Amabile, T. M. (1996). Creativity in context. New York: Westview Press.

Amanchukwu, R. N., Stanley, G. J., \& Ololube, N. P. (2015). A review of leadership theories, principles and styles and their relevance to educational management. Management, 5(1), 6-14.

Arendt, L. A. (2009). Transformational leadership and follower creativity: The moderating effect of leader humor. Review of Business Research, 9(4), 100-106.

Avolio, B. J., Howell, J. M., \& Sosik, J. J. (1999). A funny thing happened on the way to the bottom line: Humor as a moderator of leadership style effects. Academy of management journal, 42(2), 219-227.

Aycan, Z. 2006. Paternalism: Towards conceptual refinement and operationalization. In K. S. Yang, K. K. Hwang, \& U. Kim (Eds.), Scientific advances in indigenous psychologies: Empirical, philosophical, and cultural contributions: 445-466. London: Sage Ltd.

Bakan, İ., Erşahan, B., Büyükbeşe, T., Doğan, İ. F., \& İlker, K. (2015). Dönüşümcü ve etkileşimci liderlik ile öğretmenlerin tükenmişlik düzeyleri arasındaki ilişki. Uluslararası İktisadi ve İdari İncelemeler Dergisi, 7(14), 201-222.

Bass, B. (1998). Transformational leadership: Individual, military and educational impact. Lawrence Erlbaum Associates: Mahwah, NJ.

Bass, B. M., \& Stogdill, R. M. (1990). Bass \& Stogdill's handbook of leadership: Theory, research, and managerial applications. New York: Free Press.

Bertocci, D. I. (2009). Leadership in organizations: There is a difference between leaders and managers. Plymouth: University Press of America.

Bowers, J. D. (2015). Leading versus Managing. Law Prac., 41, 6. 
Briton, N. J., \& Hall, J. A. (1995). Beliefs about female and male nonverbal communication. Sex Roles, 32(1), 79 90.

Bulmer, M. G. (2012). Principles of statistics. Dover: Courier Corporation.

Cansoy, R., \& Polatcan, M. (2018). Examination of instructional leadership research in Turkey. International Online Journal of Educational Sciences, 10(1), 276-291.

Carless, S. A., Wearing, A. J., \& Mann, L. (2000). A short measure of transformational leadership. Journal of business and psychology, 14(3), 389-405.

Çelik, V. (2004). Liderlik. In Y. Özden (Ed.), Eğitim ve okul yöneticiliği el kitabı. Ankara: Pegem A Yayıncılık.

Cemaloğlu, N. (2013). Liderlik. In S. Özdemir (Ed.), Eğitim yönetiminde kuram ve uygulama (pp. 1-8). Ankara: Pegem Akademi Yayınları.

Cemaloğlu, N., Recepoğlu, E., Şahin, F., Daşcl, E., \& Köktürk, O. (2012). Mizah davranışları ölçeğinin geliştirilmesi: Geçerlik ve güvenirlik çalışması. Türk Eğitim Bilimleri Dergisi, 10(4), 694-716.

Clouse, R. W., \& Spurgeon, K. L. (1995). Corporate analysis of humor. Psychology: A journal of human behavior, 32(3), 1-24.

Conger, J. A. (1989). The charismatic leader: Beyond the mystique of exceptional leadership. San Francisco, CA: Jossey-Bass.

Conger, J. A., \& Kanungo, R. N. (1987). Toward a behavioral theory of charismatic leadership in organizational settings. Academy of Management Review, 12(4), 637-647.

Covey, S. R. (2005). 8'inci Alışkanlık. İstanbul: Sistem Yayıncılık.

Cramer, D. (1997). Basic statistics for social research: Step-by-step calculations and computer techniques using minitab. London: Routledge.

Crawford, C. B. (1994). Theory and implications regarding the utilization of strategic humor by leaders. Journal of Leadership Studies, 1(4), 53-68.

Fraenkel, J. R., \& Wallen, N. E. (2006). How to design and evaluate research in education with PowerWeb (6th ed.). New York, NY: McGraw-Hill.

Csikszentmihalyi, M. (1996). Flow and the psychology of discovery and invention. New York: Harper Collins.

Decker, W. H., \& Rotondo, D. M. (2001). Relationships among gender, type of humor, and perceived leader effectiveness. Journal of Managerial Issues, 13(4),450-465.

Dienstbier, R. A. (1995). The impact of humor on energy, tension, task choices, and attributions: Exploring hypotheses from toughness theory. Faculty Publications, Department of Psychology, 19(4), 265-267.

Dixon, N. F. (1980). Humor: Cognitive alternative to stress? In I. G. Sarason \& C. D. Spielberger (Eds.), Stress and anxiety (Vol. 7, pp. 281-289). Washington: Hemisphere.

Downton, J. V. (1973). Rebel leadership: Commitment and charisma in the revolutionary process. New York, NY: Free Press.

Dubinsky, A. J., Yammarino, F. J., Jolson, M. A., \& Spangler, W. D. (1995). Transformational leadership: An initial investigation in sales management. Journal of Personal Selling \& Sales Management, 15(2), 1731.

Dulewicz, V., \& Higgs, M. (2005). Assessing leadership styles and organisational context. Journal of Managerial Psychology, 20(2), 105-123.

Dulewicz, V., \& Higgs, M. J. (2004). Design of a new instrument to assess leadership dimensions and styles. Selection and development review, 20(2), 7-12.

Duncan, W. J. (1982). Humor in management: Prospects for administrative practice and research. Academy of Management Review, 7(1), 136-142.

Duncan, W. J., Smeltzer, L. R., \& Leap, T. L. (1990). Humor and work: Applications of joking behavior to management. Journal of Management, 16(2), 255-278.

Ercan, Ü., \& Sığrı, Ü. (2015). Kültürel Değerlerin Liderlik Özelliklerine Etkisi: Türk ve Amerikalı Yöneticiler Üzerine Bir Araştırma. Amme İdaresi Dergisi, 48(3), 95-126.

Ertürk, M. (2000). İşletmelerde yönetim ve organizasyon. İstanbul: Beta Basım Yayım Dağıtım. 
Evans, J. D. (1996). Straightforward statistics for the behavioral sciences. Pacific Grove, CA: Brooks/Cole Publishing

Farh, J. L., \& Cheng, B. S. (2000). A cultural analysis of paternalistic leadership in Chinese organizations. In J. T. Li, Tsui, A. S. \& E. Weldon (eds), Management and organizations in the Chinese context (pp. 84127). London: Palgrave Macmillan.

Field, A. (2013). Discovering statistics using SPSS (4th ed.). London: Sage publications.

George, D., \& Mallery, M. (2010). SPSS for Windows Step by Step: A Simple Guide and Reference, 17.0 update (10th ed.). Boston: Pearson.

Goffee, R., \& Jones, G. (2000). Why should anyone be led by you? Harward Business Review (SeptemberOctober), 63-70.

Göka, E. (2009). Türklerde liderlik ve fanatizm. İstanbul: Timaş Yayınları.

Goldstein, J. H. (1976). Theoretical notes on humor. Journal of Communication, 26(3), 104-112.

Goswami, A., Nair, P., Beehr, T., \& Grossenbacher, M. (2016). The relationship of leaders' humor and employees' work engagement mediated by positive emotions: Moderating effect of leaders' transformational leadership style. Leadership \& Organization Development Journal, 37(8), 1083-1099.

Gruner, C. R. (1997). The game of humor: A comprehensive theory of why we laugh. New Brunswick, NJ: Transaction.

Hahs-Vaughn, D. L., \& Lomax, R. G. (2013). An introduction to statistical concepts. New York: Routledge.

Hayek, M., Novicevic, M. M., Humphreys, J. H., \& Jones, N. (2010). Ending the denial of slavery in management history: Paternalistic leadership of Joseph Emory Davis. Journal of Management History, 16(3), 367-379.

Higgs, M., \& Rowland, D. (2001). Developing change leaders: Assessing the impact of a development programme. Journal of Change Management, 2(1), 47-64.

Hof, R., Rebello, K., \& Burrows, P. (1996). Scott McNealy's rising sun. Business Week, 22, 66-73.

Hogan, R., Curphy, G. J., \& Hogan, J. (1994). What we know about leadership: Effectiveness and personality. American psychologist, 49(6), 493-504.

Holmes, J., \& Marra, M. (2006). Humor and leadership style. Walter de Gruyter, 19(2), 119-138.

House, R., \& Dessler, G. (1974). The path goal theory of leadership: Some post hoc and a priori tests. In J. Hunt \& L. Larson (Eds.), Contingency Approaches to Leadership Carbondale Southern Illinois University Press.

House, R. J. (1976). A 1976 theory of charismatic leadership. Paper presented at the 4th Biennial Leadership Symposium, Southern Illinois University.

Hudson, W. G. (1980). The role of humor in John F. Kennedy's 1960 presidential campaign. Unpublished doctoral dissertation. Southern Illinois University. Carbondale, IL.

Jones, G. E., \& Bear, S. E. (2018). Gender Differences and Perceived Efficacy of Humor Styles in the Workplace. In Emerging Challenges in Business, Optimization, Technology, and Industry (pp. 199-203): Springer.

Jung, D. I., Chow, C., \& Wu, A. (2003). The role of transformational leadership in enhancing organizational innovation: Hypotheses and some preliminary findings. The Leadership Quarterly, 14(4-5), 525-544.

Kahn, W. A. (1989). Toward a sense of organizational humor: Implications for organizational diagnosis and change. The Journal of applied behavioral science, 25(1), 45-63.

Katz, J. (1996). Is this the perfect place to work. Los Angeles Times Magazine, June, 9(32), 375-403.

Keçecioğlu, T. (1998). Liderlik ve liderler. İstanbul: Kalder.

Koçel, T. (2001). İşletme yöneticiliği (yönetim ve organizasyon, organizasyonlarda davranış, klasik-modernçağdaş ve güncel yaklaşımlar) İstanbul: Beta.

Köksal, O. (2011). Bir kültürel liderlik paradoksu: Paternalizm. Mustafa Kemal Üniversitesi Sosyal Bilimler Enstitüsü Dergisi, 8(15), 101-122.

Lee, D. (2015). The impact of leader's humor on employees' creativity: The moderating role of trust in leader. Seoul Journal of Business, 21(1), 59-86. 
Lippitt, G. (1982). Humor: A laugh a day keeps the incongruities at bay. Training and Development Journal, 36(11), 98-100.

Locke, E. A. (1999). The essence of leadership: The four keys to leading successfully. Boston: Lexington Books.

Lovaglia, M. J., Rogalin, C. L., Soboroff, S. D., Kelley, C. P., \& Lucas, J. W. (2008). Humor and the Effectiveness of Diverse Leaders. In J. Clay-Warner \& D. T. Robinson (Eds.), Social Structure and Emotion (pp. 2135). San Diego, CA: Elsevier.

Lussier, B., Grégoire, Y., \& Vachon, M.-A. (2017). The role of humor usage on creativity, trust and performance in business relationships: An analysis of the salesperson-customer dyad. Industrial Marketing Management, 65, 168-181.

Ma, Y., Cheng, W., Ribbens, B. A., \& Zhou, J. (2013). Linking ethical leadership to employee creativity: Knowledge sharing and self-efficacy as mediators. Social Behavior and Personality: An international journal, 41(9), 1409-1419.

Malone, P. B. (1980). Humor: a double-edged tool for today's managers? Academy of Management Review, 5(3), 357-360.

Martin, J. (2015). Transformational and transactional leadership: An exploration of gender, experience, and institution type. Portal: Libraries and the Academy, 15(2), 331-351.

Martin, R. A. 2007. The psychology of humor: An integrative approach. Amsterdam, Netherlands: Elsevier

Martin, R. A., \& Lefcourt, H. M. (1983). Sense of humor as a moderator of the relation between stressors and moods. Journal of personality and social psychology, 45(6), 1313-1324.

Martinez, P. G. (2003). Paternalism as a positive form of leader-subordinate exchange: Evidence from Mexico. Management Research: Journal of the Iberoamerican Academy of Management, 1(3), 227-242.

Meliones, J. (2000). Saving money, saving lives. Harvard business review, 78(6), 57-65.

Meyer, J. (1990). Ronald Reagan and humor: A politician's velvet weapon. Communication Studies, 41(1), 7688.

Mulkay, M. J. (1988). On humor: Its nature and its place in modern society. Cambridge: Polity Press.

Murdock, M. C., \& Ganim, R. M. (1993). Creativity and humor: Integration and incongruity. The Journal of Creative Behavior, 27(1), 57-70.

Mussolino, D., \& Calabrò, A. (2014). Paternalistic leadership in family firms: Types and implications for intergenerational succession. Journal of Family Business Strategy, 5(2), 197-210.

Napier, R. W., \& Gershenfeld, M. K. (1993). Groups: Theory and experience. Geneva, Illinois: Houghton Mifflin.

Northouse, P. G. (2013). Leadership: Theory and practice: Sage publications.

Ören, K., Acar, H., \& Kandemir, H. (2016). Refah devleti paradoksu olarak kamuda taşeron çalışma sistemi: Isparta örneği. HAK-İŞ Uluslararası Emek ve Toplum Dergisi, 5(11), 154-183.

Öztop, İ. (2008). Liderlik tarzları ve örgüt kültürü tipleri arasındaki ilişki ve bu ilişkinin nitel performans üzerine etkisi (MsD), Gebze Yüksek Teknoloji Enstitüsü, İzmit.

Pellegrini, E. K., \& Scandura, T. A. (2006). Leader-member exchange (LMX), paternalism, and delegation in the Turkish business culture: An empirical investigation. Journal of international business studies, 37(2), 264-279.

Potts, J. (2009). A history of charisma: Springer.

Priest, R. F., \& Swain, J. E. (2002). Humor and its implications for leadership effectiveness. Humor, 15(2), 169190.

Pundt, A., \& Venz, L. (2017). Personal need for structure as a boundary condition for humor in leadership. Journal of Organizational Behavior, 38(1), 87-107.

Recepoğlu, E. (2011). Öğretmen algılarına göre okul müdürlerinin mizah tarzları ile öğretim liderliği davranışları ve okulun örgütsel sağlı̆̆1 arasındaki ilişki. Doctoral dissertation, Gazi Üniversitesi, Ankara. 
M. Ergün - M. Ö. Akcaoğlu 12/1 (2020) 921-937

Recepoğlu, E., \& Özdemir, S. (2012). Okul müdürlerinin mizah tarzları ile öğretim liderliği davranışları arasındaki ilişki. İnönü Üniversitesi Eğitim Fakültesi Dergisi, 13(3), 23-42.

Rizzo, B. J., Wanzer, M. B., \& Booth-Butterfield, M. (1999). Individual differences in managers' use of humor. Subordinate perceptions of managers' humor. Communication Research Reports, 16(4), 360-369.

Robinson, M. D., \& Johnson, J. (1997). Is it emotion or is it stress? Gender stereotypes and the perception of subjective experience. Sex Roles, 36(3-4), 235-258.

Romero, E. J., \& Cruthirds, K. W. (2006). The use of humor in the workplace. Academy of Management Perspectives, 20(2), 58-69.

Şenol, B. (2015). Creativity and sense of humor of elementary school principals. Unpublished master's thesis. Dokuz Eylül Üniversitesi Eğitim Bilimleri Enstitüsü, İzmir.

Sezgin, F. (2013). Okul yöneticisi ve liderlik. In S. Özdemir (Ed.), Türk eğitim sistemi ve okul yönetimi. Ankara: Pegem Akademi Yayıncilik.

Shamir, B. (1995). Social distance and charisma: Theoretical notes and an exploratory study. The Leadership Quarterly, 6(1), 19-47.

Shaw, M. E. (1955). A comparison of two types of leadership in various communication nets. The Journal of Abnormal and Social Psychology, 50(1), 127.

Singer, M. S., \& Singer, A. (1990). Situational constraints on transformational versus transactional leadership behavior, subordinates' leadership preference, and satisfaction. The Journal of Social Psychology, 130(3), 385-396.

Smith, J. W., \& Khojasteh, M. (2014). Use of humor in the workplace. International Journal of Management \& Information Systems, 18(1), 71-78.

Timmers, M., Fischer, A., \& Manstead, A. (2003). Ability versus vulnerability: Beliefs about men's and women's emotional behaviour. Cognition \& Emotion, 17(1), 41-63.

Türesin, T. H., \& Köse, S. (2015). Örgüt çalışanlarının paternalistik liderlik algıları ve öğrenilmiş güçlülük düzeyleri arasındaki ilişkilerin incelenmesi. Uluslararası Yönetim İktisat ve İşletme Dergisi, 11(26), 2956.

Vernon, P. A., Martin, R. A., Schermer, J. A., Cherkas, L. F., \& Spector, T. D. (2008). Genetic and environmental contributions to humor styles: A replication study. Twin Res Hum Genet, 11(1), 44-47.

Voich, D. (1995). Comparative empirical analysis of cultural values and perceptions of political economy issues. Westport, CT: Praeger Publishers.

Weber, M. (1947). The theory of social and economic organization: Oxford University Press.

Yang, I., Kitchen, P. J., \& Bacouel-Jentjens, S. (2017). How to promote relationship-building leadership at work? A comparative exploration of leader humor behavior between North America and China. The International Journal of Human Resource Management, 28(10), 1454-1474.

Yirci, R., Özdemir, T., \& Kartal, E. (2016). Okul yöneticilerinin mizah yönelimleri. İnsan ve Toplum Bilimleri Araştırmaları Dergisi, 5(8), 2479-2495.

Yue, X. D., \& Hui, A. N. (2015). Humor styles, creative personality traits, and creative thinking in a Hong Kong sample. Psychological Reports, 117(3), 845-855.

Yukl, G. A. (2010). Leadership in organizations. Upper Saddle River, New Jersey: Pearson.

Ziv, A. (1990). Humor and giftedness. Journal for the Education of the Gifted, 13, 332-345. 